\title{
Progesterone pretreatment has a direct effect on GnRH- induced preovulatory follicles to determine their ability to develop into normal corpora lutea in anoestrous ewes
}

\author{
M. G. Hunter, J. A. Southee, B. J. McLeod and W. Haresign
}

A.F.R.C. Research Group on Hormones and Farm Animal Reproduction, University of Nottingham, Faculty of Agricultural Science, Sutton Bonington, Loughborough, Leics, LE12 SRD, U.K.

Summary. In two experiments carried out during seasonal anoestrus, Romney Marsh ewes were treated with small-dose ( $250 \mathrm{ng}$ ) multiple injections of $\mathrm{GnRH}$ at 2 -h intervals with and without progesterone pretreatment. In Exp. 1, 8/8 progesterone-primed ewes ovulated and produced functionally normal corpora lutea compared with $2 / 9$ non-primed ewes.

Follicles were recovered from similarly treated animals 18 or $28 \mathrm{~h}$ after the start of $\mathrm{GnRH}$ treatment (at least $14 \mathrm{~h}$ before the estimated time of the $\mathrm{LH}$ peak) and assessed in terms of diameter, granulosa cell number, oestradiol, testosterone and progesterone concentrations in the follicular fluid, oestradiol production in vitro and binding of ${ }^{125}$ I-labelled hCG to granulosa and theca. There were no significant differences in any of these measures in 'ovulatory' follicles recovered from the progesterone-pretreated compared to non-pretreated animals.

In Exp. 2, follicles were removed from similar treatment groups just before and $2 \mathrm{~h}$ after the start of the LH surge. Unlike 'ovulatory' follicles recovered from the nonpretreated ewes, those recovered from progesterone-pretreated ewes responded to the LH surge by significantly increasing oestradiol secretion $(P<0.01)$ and binding of ${ }^{125}$ I-labelled hCG $(P<0.05)$ to granulosa cells. Overall there was also more $(P<0.05)$ hCG binding to granulosa and theca cells from progesterone-pretreated animals. Non-ovulatory follicles recovered from progesterone-primed ewes had more $(P<0.05)$ binding of ${ }^{125} \mathrm{I}$-labelled $\mathrm{hCG}$ to theca and a higher testosterone concentration in follicular fluid $(P<0.05)$ than did those from non-primed ewes.

These results suggest that inadequate luteal function after repeated injections of GnRH may be due to a poor response to the LH surge indicative of a deficiency in the final maturational stages of the follicle.

\section{Introduction}

Treatment of seasonally anoestrous ewes with a single injection of a large dose of GnRH results in an immediate preovulatory-type LH surge followed by ovulation, but this is not followed by normal luteal function, as assessed by peripheral plasma progesterone concentrations (Haresign, Foster, Haynes, Crighton \& Lamming, 1975). In addition, the induced corpora lutea are of lower weight, have a lower progesterone content and a much reduced ability to secrete progesterone in vitro than normal corpora lutea (McNeilly, Hunter, Land \& Fraser, 1981; J. A. Southee \& M. G. Hunter, unpublished observations). Haresign \& Lamming (1978) produced evidence which suggested that this functional incompetence was due to inadequate follicle development before the LH surge.

It has been suggested that it is the increasing frequency of LH episodes that occurs after luteal regression that controls the final stages of follicle development in the cyclic ewe (Baird, 1978; Baird, 
Swanston \& McNeilly, 1981; McNatty, Gibb, Dobson \& Thurley, 1981). Indeed, repeated injections of LH (McNeilly, O'Connell \& Baird, 1982) or GnRH (McLeod, Haresign \& Lamming, 1982a; McNatty, Ball, Gibb, Hudson \& Thurley, 1982a), administered to seasonally anoestrous ewes to mimic the pattern of LH secretion which occurs during the follicular phase of the cycle, will induce ovulation. Nevertheless, this too is often followed by abnormal luteal function in the majority of animals (McLeod et al., 1982a). However, a period of progesterone priming before the start of GnRH treatment does lead to normal luteal function (McLeod et al., 1982a; McLeod \& Haresign, 1984). The interval from the start of GnRH treatment to the onset of the LH surge has been reported to be significantly longer in the progesterone-pretreated ( $\sim 34 \mathrm{~h})$ compared to nonpretreated $(\sim 22 \mathrm{~h}$ ) animals (McLeod et al., 1982a) and indicates that inadequate luteal function in the non-pretreated animals may be due to too short a period of exposure of developing follicles to episodic LH secretion before the LH surge.

The present studies were designed to test this hypothesis by comparing biochemical aspects of follicle development before ovulation in animals in which normal and abnormal luteal function would be expected.

\section{Materials and Methods}

\section{Animals and management}

Romney Marsh ewes (mean \pm s.e.m. bodyweight $60.2 \pm 5.8 \mathrm{~kg}$ ) were used during seasonal anoestrus in August and early September, 1982 (Exp. 1) and during July and August 1983 (Exp. 2). The 108 ewes were housed under conditions of natural daylength and temperature, and fed concentrates and hay, with water always available. Multiple injections of $250 \mathrm{ng}$ synthetic $\mathrm{GnRH}$ (Lutal: Fabwerke Hoechst AG, Frankfurt, West Germany) in $2 \mathrm{ml}$ sterile saline $(9 \mathrm{~g} \mathrm{NaCl} / 1)$ were administered via an indwelling jugular vein catheter. Ewes pretreated with progesterone received 3 progesterone implants (Sil-Estrus: Ceva, Paris, France), containing $385 \mathrm{mg}$ progesterone in a silicone-elastomer matrix, inserted subcutaneously in the axilla region 12 days before $\mathrm{GnRH}$ treatment and these were removed immediately after the second GnRH injection.

\section{Treatments and sampling procedures}

The treatment regimens for individual groups of ewes for both experiments are presented in Table 1, together with information on the purpose for which the ewes were used. In both experiments progesterone-primed and non-primed ewes were induced to ovulate with GnRH treatment (Exp. 1, Groups $1 \& 2$; Exp. 2, Groups $6 \&$ 7) for studies of the incidence of normal luteal function. Similarly treated groups of ewes were slaughtered at various times before or just after the start of the preovulatory LH surge for the collection of ovarian follicles.

In-vivo estimates of the incidence of normal luteal function. Two groups of 10 seasonally anoestrous ewes received $250 \mathrm{ng}$ GnRH every $2 \mathrm{~h}$ for $48 \mathrm{~h}$, with (Group 2) or without (Group 1) a 12-day period of progesterone pretreatment in Exp. 1. For Exp. 2, progesterone-pretreated ewes (Group 7; N $=5$ ) received $2-\mathrm{h}$ injections of $250 \mathrm{ng} \mathrm{GnRH}$ for $36 \mathrm{~h}$, immediately followed by a single large bolus injection of $125 \mu \mathrm{g} \mathrm{GnRH}$. In the non-pretreated animals (Group 6, N=5) the large bolus injection of $125 \mu \mathrm{g} \mathrm{GnRH}$ was given after only $24 \mathrm{~h}$ of low-dose injections of GnRH (see Table 1). The bolus injection was designed to synchronize the time of the preovulatory $\mathbf{L H}$ surge and its time of administration was determined from the actual times of the natural LH surge recorded in Exp. 1 for progesterone-primed and non-primed ewes. In both experiments, blood samples $(2 \mathrm{ml}$ ) for LH determination were collected via the catheter at 2 -h intervals for $48 \mathrm{~h}$. Daily blood samples $(10 \mathrm{ml})$ for progesterone determination were collected by jugular venepuncture for 17 days from the time of the start of GnRH treatment. Laparoscopy was performed under 
Table 1. Summary of treatment schedules, time of slaughter after the start of multiple injections of low doses of GnRH in ewes and experimental purpose of the different treatment groups for Exps 1 and 2

\begin{tabular}{|c|c|c|c|c|c|c|}
\hline Group & $\mathrm{N}$ & $\begin{array}{l}\text { Progesterone } \\
\text { pretreatment }\end{array}$ & $\begin{array}{l}\text { Duration of } 2-\mathrm{h} \\
\text { injections of } \\
250 \mathrm{ng} \\
\text { GnRH or } \\
\text { saline } \\
\text { vehicle }(\mathrm{h})\end{array}$ & $\begin{array}{c}\text { Time of bolus } \\
\text { injection } \\
(125 \mu \mathrm{g}) \\
\text { of GnRH (h) }\end{array}$ & $\begin{array}{l}\text { Time of } \\
\text { slaughter } \\
\text { (h) }\end{array}$ & Purpose* \\
\hline \multicolumn{7}{|c|}{ Experiment 1} \\
\hline 1 & 10 & - & $48 \mathrm{GnRH}$ & - & - & CL \\
\hline 2 & 10 & + & $48 \mathrm{GnRH}$ & - & - & $\mathrm{CL}$ \\
\hline 3 & 18 & - & $18 \mathrm{GnRH}$ & - & 18 & Follicles \\
\hline 4 & 10 & + & $18 \mathrm{GnRH}$ & - & 18 & Follicles \\
\hline 5 & 10 & + & $28 \mathrm{GnRH}$ & - & 28 & Follicles \\
\hline \multicolumn{7}{|c|}{ Experiment 2} \\
\hline 6 & 5 & - & $24 \mathrm{GnRH}$ & 24 & - & CL \\
\hline 7 & 5 & + & $36 \mathrm{GnRH}$ & 36 & - & CL \\
\hline 8 & 8 & - & 24 GnRH & - & 24 & Follicles \\
\hline 9 & 8 & - & 24 GnRH & 24 & 26 & Follicles \\
\hline 10 & 8 & + & $36 \mathrm{GnRH}$ & - & 36 & Follicles \\
\hline 11 & 8 & + & $36 \mathrm{GnRH}$ & 36 & 38 & Follicles \\
\hline 12 & 8 & - & 36 saline & - & 36 & Follicles \\
\hline
\end{tabular}

* Ewes in individual treatment groups were used for an in-vivo estimate of the incidence of normal luteal function (CL) with different treatment regimens or the ovaries were removed at slaughter and the follicles subjected to a variety of biochemical studies (see text).

barbiturate anaesthesia (Sagatal: May \& Baker, Dagenham, U.K.) 4 days after the end of GnRH treatment to assess ovarian activity.

Timing of collection of ovarian tissue (Exp. 1). The ovaries from animals that had been pretreated with progesterone were collected at slaughter at $18 \mathrm{~h}$ (Group $4 ; \mathrm{N}=10$ ) or $28 \mathrm{~h}$ (Group $5 ; \mathrm{N}=10$ ) after the onset of 2-h injections of $250 \mathrm{ng} \mathrm{GnRH}$. A similar group of animals that had not been progesterone-primed (Group 3; $N=18$ ) was slaughtered $18 \mathrm{~h}$ after the start of low-dose GnRH treatment (Table 1). These slaughter times were calculated on the basis of the results of McLeod et al. (1982a) to provide follicles approximately $4-6 \mathrm{~h}$ before the presumed time of the LH peak for Groups 3 and 5. Ewes in Group 4 allowed direct comparison of follicles after the same exposure time to episodic LH secretion with and without progesterone priming. Animals were treated and slaughtered in batches of 8, containing 4 ewes from Group 3, 2 from Group 4 and 2 from Group 5, except for one instance when only 2 ewes from Group 3 were slaughtered with 2 each from Groups 4 and 5. Blood samples for LH determination were collected from all ewes at 2-h intervals from the start of treatment until the time of slaughter.

Timing of collection of ovarian tissue (Exp. 2). For the collection of ovarian tissue, groups of 8 ewes were slaughtered after treatment with GnRH or saline vehicle alone. Ewes in Group 8 were slaughtered after $24 \mathrm{~h}$ of 2-h injections of $250 \mathrm{ng} \mathrm{GnRH}$ without progesterone pretreatment, while those in Group 10 were slaughtered after $36 \mathrm{~h}$ of 2 -h injections of $250 \mathrm{ng} \mathrm{GnRH}$ following a 12-day period of progesterone priming. Treatment schedules for Groups 9 and 11 were identical to those for Groups 8 and 10, respectively, except that a single bolus injection of $125 \mu \mathrm{g} \mathrm{GnRH}$ was given at $24 \mathrm{~h}$ and $36 \mathrm{~h}$ respectively after the start of pulsatile GnRH injections and the ewes were slaughtered $2 \mathrm{~h}$ later. Control ewes in Group 12 were treated with saline vehicle alone for $36 \mathrm{~h}$ and then slaughtered. Blood samples for $\mathrm{LH}$ determination were collected from all ewes at 2 -h intervals from the start of treatment until the time of slaughter. 
Slaughter times for Exp. 2 were calculated on the basis of the results of Exp. 1, so that ovaries would be obtained either just before (Groups $8 \& 10$ ) or 2 h after (Groups $9 \& 11$ ) the start of the LH surge. A pilot experiment had been carried out in which 8 ewes were pretreated with progesterone followed by GnRH (250 ng) at 2-h intervals for $36 \mathrm{~h}$. Ovaries were recovered $0,2,4$ or $6 \mathrm{~h}(\mathrm{~N}=2$ per group) after the administration of a bolus injection $(125 \mu \mathrm{g})$ of $\mathrm{GnRH}$. Oestradiol production by the ovulatory follicles during a 2 -h incubation period was found to be highest from follicles recovered $2 \mathrm{~h}$ after the bolus injection.

Ovaries collected at the time of slaughter in both experiments were transported to the laboratory in chilled Hanks Balanced Salt Solution (HBSS) (Flow Labs, Irvine, U.K.).

\section{Follicle dissection and classification (Exp. 1)}

All follicles $\geqslant 4 \mathrm{~mm}$ in diameter were isolated, dissected free of connective tissue under a magnifying dissection glass, and their diameters measured on a millimeter grid scale. Follicular fluid was aspirated with a Hamilton syringe, transferred into $1 \mathrm{ml} \mathrm{HBSS}$ and centrifuged at $1000 \mathrm{~g}$ for 10 min to pellet any granulosa cells removed with the fluid. The supernatant (HBSS containing the follicular fluid) was decanted and stored at $-20^{\circ} \mathrm{C}$ until assayed for steroid content.

The empty follicle shell was placed in $3 \mathrm{ml} \mathrm{HBSS}$ (without $\mathrm{Ca}^{2+}$ and $\mathrm{Mg}^{2+}$ to prevent clumping of the cells) and cut in half using fine scissors. Granulosa cells were scraped into the liquid using a round-ended Pasteur pipette and added to the pellet remaining from the follicular fluid. A further $2 \mathrm{ml}$ HBSS were added to the scraped follicle halves and pipetted up and down 10 times to dislodge any remaining granulosa cells. This $2 \mathrm{ml}$ was pooled with the scraped cells and centrifuged at $1000 \mathrm{~g}$ for $10 \mathrm{~min}$. The thecal tissue was stored in liquid nitrogen $\left(\mathrm{N}_{2}\right)$ until required for binding measurements. Follicles obtained from other animals were processed as above and examined histologically. Very little granulosa cell contamination of the thecal tissue was noted.

The pellet of granulosa cells was gently resuspended in $1 \mathrm{ml} \mathrm{HBSS}$ and cell numbers counted using a haemocytometer. Samples $\left(30 \mu \mathrm{l}\right.$ ) of this suspension (containing $0.93-20.4 \times 10^{4}$ cells) were added to $1 \mathrm{ml}$ Eagle's Basal Medium (BME) (Flow Labs), containing $20 \mathrm{~mm}$-Hepes buffer and $0.1 \%$ bovine serum albumin (BSA) (Fraction V: Sigma Chemical Co., Dorset, U.K.) to be used for the measurement of oestradiol production rates. The incubations set up were controls $(\mathrm{N}=3)$ or plus testosterone $(\mathrm{N}=3)$ at a final concentration in the medium of $100 \mathrm{ng} / \mathrm{ml}$ (added in $10 \mu \mathrm{l}$ ethanol). The tubes were incubated for $2 \mathrm{~h}$ at $37^{\circ} \mathrm{C}$ in a shaking water bath and then stored at $-20^{\circ} \mathrm{C}$ until assayed for oestradiol. The granulosa cells not used for incubation were centrifuged again, resuspended in phosphate-buffered saline (PBS) plus $20 \%$ glycerol and stored in liquid $\mathrm{N}_{2}$.

Based on previous studies by others (Moor, Hay, Dott \& Cran, 1978; Carson, Findlay, Clarke \& Burger, 1981; McNatty et al., 1982b), a follicle was classified as 'ovulatory' if the oestradiol in the follicular fluid was $>100 \mathrm{ng} / \mathrm{ml}$ and also if the oestradiol:testosterone ratio was $>1$ or $>2 \times 10^{6}$ granulosa cells were recovered from that follicle. All other follicles were classified as 'non-ovulatory'.

\section{Follicle dissection and classification (Exp. 2)}

All follicles $\geqslant 2 \mathrm{~mm}$ in diameter were isolated and diameters measured on a millimeter grid scale. They were then incubated for $2 \mathrm{~h}$ in $1 \mathrm{ml} \mathrm{BME}$ according to the method of Webb \& England (1982b). At the end of the incubation period the medium was stored at $-20^{\circ} \mathrm{C}$ until assayed for oestradiol and the intact follicles stored in liquid $\mathrm{N}_{2}$. After removal from liquid $\mathrm{N}_{2}$, follicles were thawed and follicular fluid aspirated and granulosa cells scraped and counted as described for Exp. 1. All granulosa cells and thecal tissue from each follicle were then used immediately for analysis of binding of ${ }^{125}$ I-labelled hCG.

Follicles were classified as 'ovulatory' if oestradiol in the follicular fluid was $>100 \mathrm{ng} / \mathrm{ml}$ and $>2 \times 10^{6}$ granulosa cells were recovered. 


\section{Binding of ${ }^{125}$ I-labelled hCG to granulosa cells and thecal tissue}

The binding of hCG was assessed with the hCG preparation CR121 (13450 i.u./mg) labelled with ${ }^{125}$ I (Amersham International plc, Amersham, U.K.) by the lactoperoxidase method of Thorell \& Johansson (1971). The specific activity of ${ }^{125} \mathrm{I}$-labelled hCG was $20 \mu \mathrm{Ci} / \mu \mathrm{g}$ with an active fraction of $40 \%$ in Exp. 1, and $28 \mu \mathrm{Ci} / \mu \mathrm{g}$ with an active fraction of $38 \%$ in Exp. 2. All receptor assays were carried out in PBS containing $0.1 \% \mathrm{BSA}$ in a final volume of $300 \mu \mathrm{l}$. No tissue was stored in liquid $\mathrm{N}_{2}$ for more than 3 months before assay. Preliminary studies had established that there was no deterioration in binding during this time. After removal of the tissue and cells from liquid $\mathrm{N}_{2}$, granulosa cells were washed twice to remove glycerol (Exp. 1) and thecal tissue was chopped with fine scissors and homogenized in $5 \mathrm{ml}$ PBS for $30 \mathrm{sec}$, and centrifuged at $2000 \mathrm{~g}$ and $4 \mathrm{C}$ for $25 \mathrm{~min}$. Thecal and granulosa cells were resuspended in $0.4 \mathrm{ml}$ PBS + BSA and $100 \mu \mathrm{l}$ samples were dispensed into 4 tubes to which were added $100 \mu 1 \mathrm{PBS}$, or $100 \mu \mathrm{l}$ (100 i.u.) hCG (Sigma) for non-specific binding and $100 \mu{ }^{125}$ I-labelled hCG containing 100000 c.p.m. Tubes were incubated for $2 \mathrm{~h}$ at $37^{\circ} \mathrm{C}$ in a shaking water bath (Exp. 1), or $16 \mathrm{~h}$ at $22^{\circ} \mathrm{C}$ (Exp. 2). The reaction was terminated by adding $2 \mathrm{ml}$ ice-cold PBS containing $0 \cdot 1 \%$ BSA and centrifuging at $2000 \mathrm{~g}$ for $25 \mathrm{~min}$. The supernatant was discarded and the pellet resuspended and recentrifuged. The supernatant was again discarded and the pellet counted for $2 \mathrm{~min}$ in a gamma counter. Protein determination was subsequently carried out on the thecal pellet using the method of Lowry, Rosebrough, Farr \& Randall (1951) and ranged from 20 to $170 \mu \mathrm{g}$ protein.

Validation of the binding assay for ${ }^{125}$ I-labelled hCG was determined using thecal and granulosa tissue from PMSG-treated anoestrous ewes and from normal cyclic animals; similar results were obtained from each type of animal. The time required for maximum binding to be reached was $2 \mathrm{~h}$ at $37^{\circ} \mathrm{C}$ and $16 \mathrm{~h}$ at $22^{\circ} \mathrm{C}$. The addition of 100000 c.p.m. ${ }^{125}$ I-labelled hCG to appropriate aliquants of follicular tissue was found to be saturating, and binding was found to increase with increasing amounts of tissue.

\section{Hormone radioimmunoassays}

Concentrations of LH in peripheral plasma were determined by the specific double-antibody radioimmunoassay of Foster \& Crighton (1974) as modified by McLeod et al. (1982b). Within this study the limit of sensitivity of the assay was $0.3 \mathrm{ng} \mathrm{NIH}-\mathrm{LH}-\mathrm{S} 18$ equiv./ml plasma and the interand intra-assay coefficients of variation were $11 \cdot 2$ and $7 \cdot 3 \%$ respectively.

Measurement of progesterone in peripheral plasma was based on the radioimmunoassay method of Haresign et al. (1975) with the following modifications. Progesterone antiserum, obtained from Specific Antisera Ltd, Cheshire, U.K., was used at a dilution of 1:4000. Duplicate volumes of plasma $(0.25 \mathrm{ml})$ were extracted with 4 volumes of light petroleum ether by mixing of the two phases for $20 \mathrm{~min}$ on a mechanical shaker (Baird \& Tatlock Ltd, London, U.K.) before freezing. Dextran-charcoal solution was made up with $0.1 \mathrm{~g}$ dextran and $0.2 \mathrm{~g}$ charcoal in $100 \mathrm{ml}$ buffer and stirred for at least $4 \mathrm{~h}$ at $4^{\circ} \mathrm{C}$ before $0.5 \mathrm{ml}$ was added to each assay tube. Scintillation fluid ( $2 \mathrm{ml}$; Fisofluor 3, Fisons plc, Loughborough, U.K.) was added to the supernatant in the scintillation vials and incubated for $30 \mathrm{~min}$ at $75^{\circ} \mathrm{C}$ before shaking and counting. The assay showed negligible cross reaction with other major steroids and within this study the limit of sensitivity was $0.1 \mathrm{ng} / \mathrm{ml}$ plasma, the mean extraction efficiency was $82.0 \pm 2.08 \%$ and both the inter- and intra-assay coefficients of variation were $<12 \%$.

Steroid concentrations in follicular fluid diluted in $1 \mathrm{ml} \mathrm{HBSS}$ were measured after extraction, and corrected for recovery losses. All three steroids showed parallelism to the standard curve after extraction. Progesterone was measured as described above and the intra-assay coefficient of variation was $<11 \%$. Oestradiol was measured by the method of Foxcroft, Elsaesser, Stickney, Haynes \& Back (1984), with a limit of sensitivity of $0.05 \mathrm{ng} / \mathrm{ml}$ and a mean recovery of $98.3 \pm 0.66 \%$. Inter- and intra-assay coefficients of variation were $<6 \%$. Testosterone was 
measured by the method of Purvis, Illius \& Haynes (1974) with similar modifications to the extraction procedure and dextran-charcoal solution as described above for the progesterone assay. The mean extraction efficiency was $85.0 \pm 1 \cdot 13 \%$, the limit of sensitivity was $0 \cdot 2 \mathrm{ng} / \mathrm{ml}$ and inter-and intra-assay coefficients of variation were $<10 \%$.

The concentrations of oestradiol in the incubation media were measured using the method described for follicular fluid, except that samples were assayed directly without prior extraction. That extraction was not required was checked by comparing values obtained by this method with values for diethyl ether-extracted aliquants taken from the same samples. The coefficient of linear correlation was $0.97(\mathrm{~N}=12)$ and serial dilutions showed parallelism with the standard curve. Inter- and intra-assay coefficients of variation were $<11 \%$.

\section{Statistical analyses}

Analysis of variance was carried out on logarithmically transformed data to reduce heterogeneity of variance, although tables of results present untransformed data. The number of degrees of freedom for each group was based on the number of sheep per treatment group. When analysis of variance indicated significant differences, individual means were compared by Duncan's Multiple Range Test. $\chi^{2}$ analysis was carried out to compare the incidence of normal luteal function in the pretreated and non-pretreated groups.

\section{Results}

\section{Validation of ${ }^{125}$ I-labelled $h C G$ binding assay}

Specificity of binding was determined by carrying out the incubation in the presence of high levels of the unlabelled hormones hCG (CR121, 0.05-1000 ng/ml), ovine LH (NIH-LH-S24, $10-10000 \mathrm{ng} / \mathrm{ml}$ ), ovine FSH (NIH-FSH-S14, 10-10000 ng/ml) and prolactin (NIH-P-S10, $10-10000 \mathrm{ng} / \mathrm{ml}$ ). The results obtained indicated that binding could be completely inhibited in the granulosa and theca cells by hCG and ovine LH, but FSH and prolactin showed very low cross-reactivity (Fig. 1).

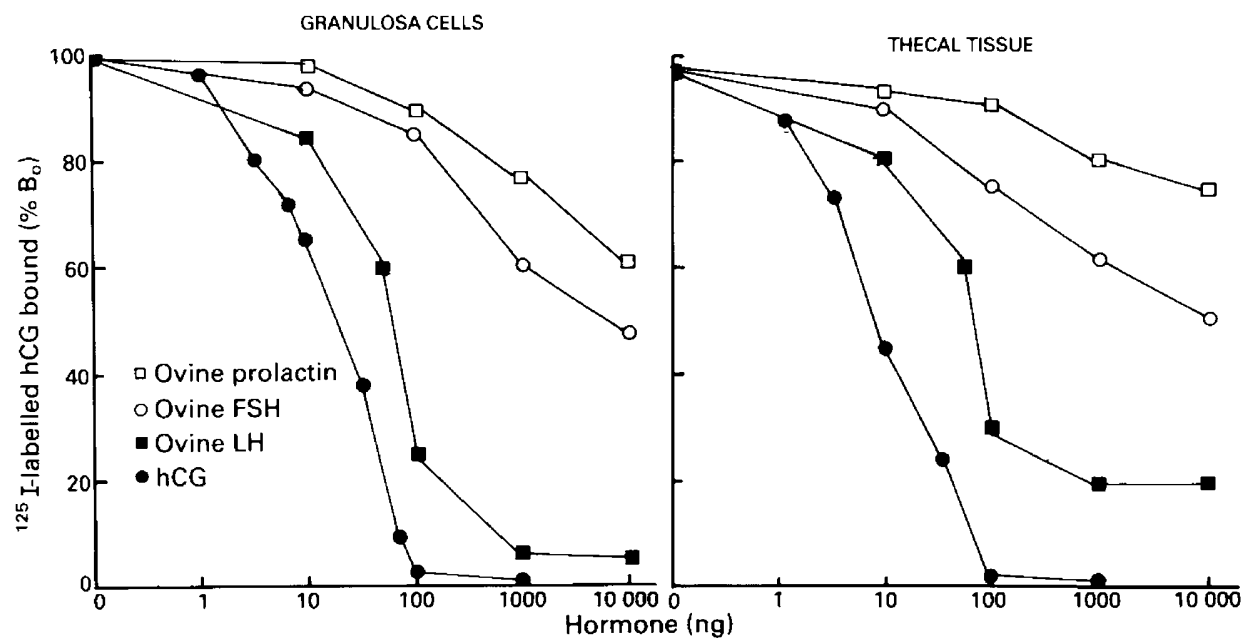

Fig. 1. Specificity of the binding of ${ }^{125} \mathrm{I}$-labelled hCG to granulosa cells and thecal tissue of sheep follicles. Cross-reactions of pituitary hormones and hCG were determined using ${ }^{125} \mathrm{I}$-labelled hCG as labelled ligand and increasing amounts of different unlabelled hormones. 


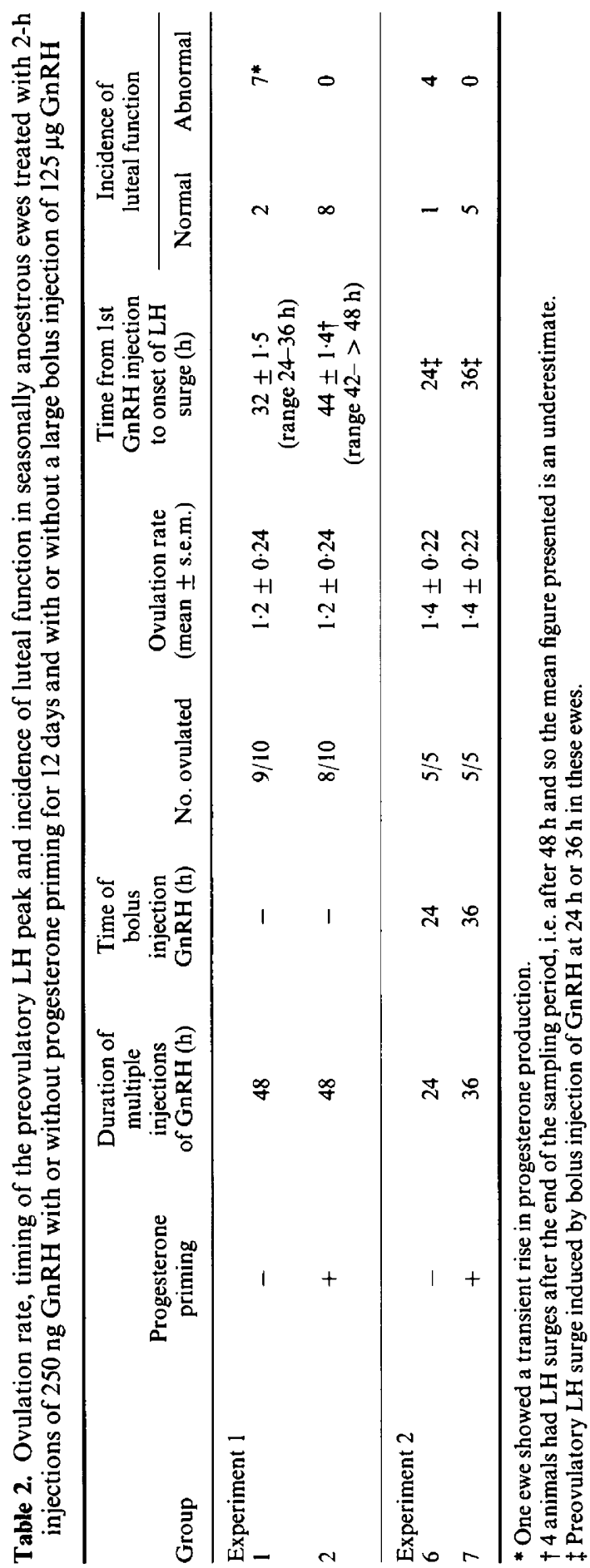


The specific activity of the ${ }^{125} \mathrm{I}$-labelled hCG was determined by dividing the c.p.m. of the $50 \%$ $\mathrm{B} / \mathrm{F}$ from an inhibition curve by the quantity (ng) of unlabelled hCG that displaced $50 \%$ of the ${ }^{125} \mathrm{I}$-labelled hCG. Scatchard analyses were carried out for ganulosa and theca cells using $5000-200000$ c.p.m. Dissociation constants $\left(K_{\mathrm{d}}\right)$ for the hCG receptors in granulosa and theca cells were $7 \cdot 5 \times 10^{-11} \mathrm{~mol} / 1$ and $4.3 \times 10^{-11} \mathrm{~mol} / 1$ with receptor concentrations of $3.2 \times 10^{-10} \mathrm{M} / \mathrm{mg}$ protein and $1.1 \times 10^{-10} \mathrm{M} / \mathrm{mg}$ protein, respectively.

\section{GnRH induction of ovulation and the incidence of normal luteal function}

Mean ovulation rates, the timing of the preovulatory LH surge and the incidence of normal luteal function for the in-vivo control treatment groups are presented in Table 2. Ovulation rates for the different treatment groups were not significantly different and animals with no corpora lutea were excluded. The interval from the start of GnRH treatment to the onset of the LH surge in Exp. 1 was $32 \pm 1.5 \mathrm{~h}$ (range $24-36 \mathrm{~h}$ ) for ewes in Group 1 receiving multiple injections of GnRH alone. In ewes pretreated with progesterone (Group 2) the mean time of the LH surge was $44 \pm 1.4 \mathrm{~h}$ for 4 of the ewes while in the remaining 4 ewes it had not begun by the end of the $48 \mathrm{~h}$ sampling period. For ewes in Exp. 2, the preovulatory LH surge was induced by a bolus injection of $125 \mu \mathrm{g} \mathrm{GnRH}$ at $24 \mathrm{~h}$ in non-progesterone primed animals and at $36 \mathrm{~h}$ in progesterone-primed ewes. All 13 ewes that were primed with progesterone and ovulated (Groups $2 \& 7$ ) showed normal luteal function (defined as an elevation in plasma progesterone concentrations for at least 8 days starting within 4 days of the $\mathrm{LH}$ surge and reaching maximum concentrations of $>1.5 \mathrm{ng} / \mathrm{ml}$ ), compared to only $3 / 14$ ewes (Groups $1 \& 6)$ which were not pretreated with progesterone $(P<0 \cdot 001)$, with no significant difference in response to progesterone priming between experiments.

Numbers, classification and activity of ovarian follicles (Exp. 1)

There was no evidence of an LH surge in any animals in Groups 3, 4 and 5 before follicles were recovered at slaughter.

Table 3. Numbers of 'ovulatory' and 'non-ovulatory' follicles recovered from GnRH-treated seasonally anoestrous ewes, together with the estimated time of collection in relation to the preovulatory LH surge, in Exps 1 and 2 (in Exp. 1 all follicles $\geqslant 4 \mathrm{~mm}$ diameter were studied, but in Exp. 2 all follicles $\geqslant 2 \mathrm{~mm}$ diameter were studied)

\begin{tabular}{|c|c|c|c|c|c|c|c|}
\hline \multirow[b]{2}{*}{ Group } & \multirow{2}{*}{$\begin{array}{c}\text { Time } \\
\text { collection of } \\
\text { follicles relative } \\
\text { to the LH peak }(\mathrm{h})^{*}\end{array}$} & \multirow{2}{*}{$\begin{array}{l}\text { No. of } \\
\text { follicles } \\
\text { dissected }\end{array}$} & \multicolumn{2}{|c|}{$\begin{array}{l}\text { 'Non-ovulatory' } \\
\text { follicles }\end{array}$} & \multicolumn{2}{|c|}{$\begin{array}{l}\text { 'Ovulatory' } \\
\text { follicles }\end{array}$} & \multirow{2}{*}{$\begin{array}{c}\text { Potential } \\
\text { ovulation } \\
\text { rate } \\
\text { (mean } \pm \text { s.e.m. })\end{array}$} \\
\hline & & & No. & $\begin{array}{l}\% \text { of } \\
\text { total }\end{array}$ & No. & $\begin{array}{l}\% \text { of } \\
\text { total }\end{array}$ & \\
\hline \multicolumn{8}{|l|}{ Experiment 1} \\
\hline $3(\mathrm{~N}=18)$ & $-14 \mathrm{~h}$ & 28 & 8 & 29 & 20 & 71 & $1.1 \pm 0.15$ \\
\hline $4(\mathrm{~N}=10)$ & $>-26 \mathrm{~h}$ & 18 & 5 & 28 & 13 & 72 & $1 \cdot 3 \pm 0 \cdot 15$ \\
\hline $5(\mathrm{~N}=10)$ & $>-16 h$ & 20 & 7 & 35 & 13 & 65 & $1 \cdot 3 \pm 0 \cdot 15$ \\
\hline \multicolumn{8}{|l|}{ Experiment 2} \\
\hline $8(\mathrm{~N}=8)$ & 0 & 40 & 28 & 70 & 12 & 30 & $1.6 \pm 0.19$ \\
\hline $9(\mathrm{~N}=8)$ & +2 & 34 & 24 & 71 & 10 & 29 & $1.3 \pm 0.28$ \\
\hline $10(\mathrm{~N}=8)$ & 0 & 45 & 32 & 71 & 13 & 29 & $1 \cdot 3 \pm 0 \cdot 15$ \\
\hline $11(\mathrm{~N}=8)$ & +2 & 39 & 29 & 74 & 10 & 26 & $1.4 \pm 0.28$ \\
\hline $12(\mathrm{~N}=6)$ & - & 30 & 30 & 100 & 0 & 0 & 0 \\
\hline
\end{tabular}

$\mathrm{N}=$ number of sheep.

* Estimated from the mean time of the recorded $\mathbf{L H}$ peak in ewes from Groups 1 and 2 in Exp. 1 receiving similar treatment regimens (see Table 2), or in relation to the induced LH peak in Exp. 2. 
Table 4. Diameter, granulosa cell number, follicular fluid steroid concentrations, in-vitro steroid secretion rates and ${ }^{125}$ l-labelled hCG binding to thecal and granulosa tissue of 'ovulatory' and 'non-ovulatory' follicles recovered from GnRH-treated anoestrous ewes in Exp. 1 (all values are mean \pm s.e.m.)

\begin{tabular}{|c|c|c|c|c|}
\hline & \multicolumn{3}{|c|}{ Ovulatory follicles } & \multirow[b]{2}{*}{$\begin{array}{c}\text { Non-ovulatory' } \\
\text { follicles } \\
\text { pooled from } \\
\text { all groups }\end{array}$} \\
\hline & $\begin{array}{l}\text { Group } 3 \\
\text { (2-h injections } \\
\text { GnRH }(250 \mathrm{ng}) \\
\text { for } 18 \mathrm{~h})\end{array}$ & $\begin{array}{l}\text { Group 4 } \\
\text { (progesterone } \\
\text { priming + 2-h } \\
\text { injections } \\
\text { GnRH }(250 \mathrm{ng} \text { ) } \\
\quad \text { for } 18 \mathrm{~h} \text { ) }\end{array}$ & $\begin{array}{l}\text { Group 5 } \\
\text { (progesterone } \\
\text { priming }+2-\mathrm{h} \\
\text { injections } \\
\text { GnRH }(250 \mathrm{ng} \text { ) } \\
\quad \text { for } 28 \mathrm{~h} \text { ) }\end{array}$ & \\
\hline No. of follicles & 20 & 13 & 13 & 20 \\
\hline $\begin{array}{l}\text { Estimated time of collection } \\
\text { relative to preovulatory } \\
\text { LH surge }(\mathrm{h})\end{array}$ & -14 & $>-26$ & $>-16$ & \\
\hline Follicular diam. (mm) & $5 \cdot 35 \pm 0 \cdot 19^{\mathrm{a}}$ & $5.31 \pm 0.17^{\mathrm{a}}$ & $5.31 \pm 0.19^{\mathrm{a}}$ & $4.35 \pm 0.12^{b}$ \\
\hline $\begin{array}{l}\text { No. of granulosa cells } \\
\text { recovered } \times 10^{-6}\end{array}$ & $3.5 \pm 0.2^{a}$ & $3 \cdot 6 \pm 0.4^{a}$ & $2 \cdot 9 \pm 0.2^{a}$ & $1.2 \pm 0.1^{b}$ \\
\hline $\begin{array}{l}\text { Oestradiol conc. in follicular } \\
\text { fluid }(\mathrm{ng} / \mathrm{ml})\end{array}$ & $163 \cdot 5 \pm 13 \cdot 7^{\mathrm{a}}$ & $150 \cdot 1 \pm 12 \cdot 3^{2}$ & $135.4 \pm 6 \cdot 5^{a}$ & $22.5 \pm 7.5^{b}$ \\
\hline $\begin{array}{l}\text { Testosterone conc. in } \\
\quad \text { follicular fluid (ng/ml) }\end{array}$ & $45 \cdot 5 \pm 12 \cdot 8$ & $45 \cdot 1 \pm 9 \cdot 2$ & $24 \cdot 3 \pm 3 \cdot 7$ & $49 \cdot 1 \pm 11 \cdot 9$ \\
\hline Oestradiol:testosterone ratio & $9 \cdot 9 \pm 2 \cdot 7^{\mathrm{a}}$ & $4.8 \pm 0.8^{2}$ & $9.0 \pm 1.9^{a}$ & $0.48 \pm 0.13^{b}$ \\
\hline $\begin{array}{l}\text { Progesterone conc. in } \\
\text { follicular fluid }(\mathrm{ng} / \mathrm{ml})\end{array}$ & $33.6 \pm 5.8$ & $29 \cdot 2 \pm 5 \cdot 6$ & $22 \cdot 6 \pm 5 \cdot 4$ & $41.6 \pm 6.9$ \\
\hline $\begin{array}{l}\text { c.p.m. }{ }^{125} \text { I-labelled hCG } \\
\text { bound/total granulosa in } \\
\text { follicle } \times 10^{-3}\end{array}$ & $13 \cdot 56 \pm 1 \cdot 80^{\mathrm{a}}$ & $8 \cdot 81 \pm 1.05^{a}$ & $11 \cdot 03 \pm 2 \cdot 57^{a}$ & $1.75 \pm 0.42^{b}$ \\
\hline $\begin{array}{l}\text { c.p.m. }{ }^{125} \text { I-labelled hCG } \\
\text { bound/total theca in } \\
\text { follicle } \times 10^{-3}\end{array}$ & $10 \cdot 33 \pm 1 \cdot 18$ & $11 \cdot 92 \pm 2 \cdot 10$ & $9.92 \pm 1.50$ & $6.51 \pm 0.91$ \\
\hline $\begin{array}{l}\text { Oestradiol production } \\
\text { Control incubations (ng } \\
\text { oestradiol/total } \\
\text { granulosa cells } / 2 \mathrm{~h} \text { ) }\end{array}$ & $\begin{array}{l}9 \cdot 96 \pm 1 \cdot 07^{\mathrm{a}} \\
(\mathrm{N}=60)\end{array}$ & $\begin{array}{l}4 \cdot 59 \pm 0.47^{a} \\
(N=39)\end{array}$ & $\begin{array}{l}5 \cdot 90 \pm 0.92^{\mathrm{a}} \\
(\mathrm{N}=39)\end{array}$ & $\begin{array}{l}0 \cdot 34 \pm 0 \cdot 13^{\mathrm{b}} \\
(\mathrm{N}=60)\end{array}$ \\
\hline $\begin{array}{l}\text { Incubations }+100 \mathrm{ng} / \mathrm{ml} \\
\text { testosterone }(\mathrm{ng} \\
\text { oestradiol } / \text { total } \\
\text { granulosa cells } / 2 \mathrm{~h})\end{array}$ & $\begin{array}{c}12 \cdot 95 \pm 1 \cdot 15^{\mathrm{a}} \\
(\mathrm{N}=60)\end{array}$ & $\begin{array}{l}8 \cdot 28 \pm 0 \cdot 67^{\mathrm{a}} \\
(\mathrm{N}=39)\end{array}$ & $\begin{array}{l}7 \cdot 85 \pm 0 \cdot 83^{\mathrm{a}} \\
(\mathrm{N}=39)\end{array}$ & $\begin{array}{l}0.57 \pm 0.13^{b} \\
(\mathrm{~N}=60)\end{array}$ \\
\hline
\end{tabular}

All granulosa cell incubations were carried out in triplicate, and total number of incubations is shown in parentheses. The results are expressed as ng oestradiol produced per total complement of granulosa cells recovered from that follicle. Values followed by different letters (a or b) are significantly different, $P<0.05$ at least (see text for details) and comparisons should be confined to rows.

The numbers of follicles $\geqslant 4 \mathrm{~mm}$ in diameter classified as 'ovulatory' or 'non-ovulatory' for the three treatment groups are summarized in Table 3. Potential ovulation rates, based on the number of 'ovulatory' follicles recovered, were not significantly different from the ovulation rates observed at laparoscopy for in-vivo control ewes in Groups 1 and 2 (see Table 2). Similar proportions of potential 'ovulatory' and 'non-ovulatory' follicles were recovered from each group. 
The results of follicle measurements and in-vitro incubations for 'ovulatory' and 'nonovulatory' follicles are summarized in Table 4. All of the 'non-ovulatory' follicles from the three treatment groups were analysed together. Follicle diameter was significantly $(P<0.01)$ smaller and the number of granulosa cells recovered was significantly $(P<0.01)$ less for 'non-ovulatory' follicles than for 'ovulatory' follicles. When considered across treatment groups follicle diameter and number of granulosa cells recovered, were significantly and positively correlated $(r=0.515$, $P<0.001)$.

There were no significant differences between any treatment groups in follicular fluid steroid concentrations (oestradiol, testosterone and progesterone) of ovulatory follicles, even though their estimated time of collection relative to the LH surge was different, although there was a tendency for follicular fluid testosterone concentrations in Group 5 to be lower than that for Groups 3 and 4. However, the follicular fluid from 'non-ovulatory' follicles contained significantly $(P<0.01)$ less oestradiol than that from 'ovulatory' follicles. 'Non-ovulatory' follicles contained more progesterone in their follicular fluid than 'ovulatory' follicles, but this difference did not quite reach significance. In spite of the wide variation in follicular fluid testosterone concentrations, the oestradiol:testosterone ratio was significantly $(P<0.01)$ higher in the 'ovulatory' follicles of all treatment groups compared to 'non-ovulatory' follicles.

Significant positive correlations were found between the number of granulosa cells recovered and both the oestradiol concentrations in follicular fluid $(r=0.59 ; P<0.001)$ and the oestradiol: testosterone ratio $(r=0 \cdot 74 ; P<0 \cdot 001)$.

Binding of ${ }^{125}$ I-labelled hCG to granulosa cells and thecal tissue in Table 4 has been expressed as number of counts bound per total complement of granulosa cells or thecal tissue in that particular follicle. None of the groups of 'ovulatory' follicles was significantly different from each other, but the granulosa of 'non-ovulatory' follicles bound significantly $(P<0.01)$ less ${ }^{125}$ I-labelled hCG than did 'ovulatory' follicles. Although thecal tissue of 'non-ovulatory' follicles bound less ${ }^{125}$ I-labelled hCG than that of 'ovulatory' follicles, there were no significant differences between treatment groups. A significant positive correlation was found between binding of ${ }^{125} \mathrm{I}$-labelled hCG to granulosa cells and oestradiol concentrations in follicular fluid $(r=0.52 ; P<0.001)$ and also between the binding capacities of granulosa and thecal tissues $(r=0.42 ; P<0.001)$.

Oestradiol production by the granulosa cells during the short-term incubations increased significantly in all groups $(P<0.05)$ when exogenous testosterone $(100 \mathrm{ng} / \mathrm{ml})$ was added as substrate. There were no significant differences between treatment groups in oestradiol secretion rates for 'ovulatory' follicles, but that from 'non-ovulatory' follicles was significantly $(P<0.01)$ less, a situation similar to oestradiol concentrations in follicular fluid.

\section{Numbers, classification and activity of ovarian follicles (Exp. 2)}

Analysis of LH profiles of animals in Exp. 2 indicated that ewes in Groups 8 and 10 were slaughtered before the onset of the preovulatory $\mathrm{LH}$ peak. However, mean $\mathrm{LH}$ concentrations at the time of slaughter for Groups $9(198 \pm 31.9 \mathrm{ng} \mathrm{NIH-LH-S18} \mathrm{equiv./ml)} \mathrm{and} 11(155 \pm 41.9 \mathrm{ng}$ NIH-LH-S18 equiv. $/ \mathrm{ml}$ ) indicated that the follicles from these ewes were collected after the onset of the preovulatory LH surge. Mean LH values immediately before slaughter for Groups 9 and 11

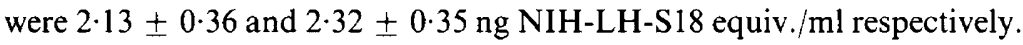

The numbers of follicles classified as 'ovulatory' or 'non-ovulatory' for the different treatment groups are shown in Table 3. No 'ovulatory' follicles were recovered from the saline-treated animals (Group 12). The potential mean ovulation rates in the four GnRH-treated groups ranged from $1 \cdot 3$ to $1 \cdot 6$, and were not significantly different from the actual ovulation rates observed at laparoscopy in similarly treated ewes (Table 2).

The follicle parameters measured in 'non-ovulatory' and 'ovulatory' follicles are summarized in Tables 5 and 6 respectively. There were no significant differences between any of the individual treatment groups in terms of follicle diameter, granulosa cell content, steroid concentrations in 
Table 5. Diameter, granulosa cell number, follicular fluid steroid concentrations and ${ }^{125}$ I-labelled hCG binding to thecal and granulosa tissue of 'non-ovulatory' follicles recovered from GnRH-treated anoestrous ewes in Exp. 2 (all values are mean \pm s.e.m.)

\begin{tabular}{|c|c|c|c|c|}
\hline $\begin{array}{l}\text { Group } 8 \\
2-\mathrm{h} \text { injections }\end{array}$ & $\begin{array}{c}\text { Group 9 } \\
\text { (2-h injections } \\
\text { GnRH (250 ng) for }\end{array}$ & $\begin{array}{c}\text { Group 10 } \\
\text { (progesterone } \\
\text { priming + } \\
\text { 2-h injections }\end{array}$ & $\begin{array}{c}\text { Group 11 } \\
\text { (progesterone } \\
\text { priming + 2-h } \\
\text { injections GnRH } \\
(250 \mathrm{ng}) \text { for } 36 \mathrm{~h}\end{array}$ & Groun 12 \\
\hline $\begin{array}{l}\text { GnRH }(250 \mathrm{ng}) \\
\quad \text { for } 24 \mathrm{~h})\end{array}$ & $\begin{array}{l}24 \mathrm{~h}+125 \mu \mathrm{g} \\
\text { GnRH at } 24 \mathrm{~h})\end{array}$ & $\begin{array}{l}\text { GnRH }(250 \mathrm{ng}) \\
\quad \text { for } 36 \mathrm{~h})\end{array}$ & $\begin{array}{c}+125 \mu \mathrm{g} \mathrm{GnRH} \\
\text { at } 36 \mathrm{~h})\end{array}$ & $\begin{array}{l}\text { (2-h injections } \\
\text { saline for } 36 \mathrm{~h})\end{array}$ \\
\hline
\end{tabular}

Estimated time of collection relative to preovulatory LH surge

(h)

No. of follicles

\begin{tabular}{|c|c|c|c|c|}
\hline 0 & +2 & 0 & +2 & - \\
\hline 28 & 24 & 32 & 29 & 30 \\
\hline $3 \cdot 3 \pm 0 \cdot 2$ & $3 \cdot 7 \pm 0 \cdot 2$ & $3 \cdot 8 \pm 0 \cdot 2$ & $3.4 \pm 0.2$ & $3 \cdot 6 \pm 0 \cdot 2$ \\
\hline $0.8 \pm 0 \cdot 1$ & $0 \cdot 9 \pm 0 \cdot 1$ & $1 \cdot 1 \pm 0 \cdot 2$ & $1 \cdot 2 \pm 0.2$ & $1 \cdot 0 \pm 0 \cdot 2$ \\
\hline $31.9 \pm 7.8$ & $56 \cdot 5 \pm 14 \cdot 2 \dagger$ & $33 \cdot 2 \pm 8 \cdot 3$ & $59.1 \pm 12.3 \uparrow$ & $43.9 \pm 8.4$ \\
\hline $119 \cdot 1 \pm 12 \cdot 7$ & $304 \cdot 2 \pm 42 \cdot 8 t$ & $151 \cdot 0 \pm 18 \cdot 6^{*}$ & $428 \cdot 7 \pm 46 \cdot 4 \dagger^{*}$ & $107 \cdot 1 \pm 19 \cdot 3$ \\
\hline $0.4 \pm 0.1$ & $0.3 \pm 0.1$ & $0 \cdot 3 \pm 0 \cdot 1$ & $0.3 \pm 0.1$ & $0 \cdot 9 \pm 0.2$ \\
\hline $22 \cdot 1 \pm 3 \cdot 1$ & $20 \cdot 2 \pm 3 \cdot 3$ & $35 \cdot 3 \pm 7 \cdot 3$ & $26 \cdot 3 \pm 2 \cdot 9$ & $30 \cdot 1 \pm 5 \cdot 5$ \\
\hline $0 \cdot 47 \pm 0 \cdot 14$ & $0.6 \pm 0.16$ & $0 \cdot 52 \pm 0 \cdot 18$ & $0 \cdot 73 \pm 0 \cdot 21$ & $0.26 \pm 0.08$ \\
\hline $3.9 \pm 0.5$ & $3.8 \pm 0.5$ & $4 \cdot 7 \pm 0.9$ & $3.9 \pm 0.7$ & $2 \cdot 9 \pm 0.4$ \\
\hline $4 \cdot 0 \pm 0 \cdot 4$ & $4.2 \pm 0.7$ & $6.8 \pm 1 \cdot 1 \dagger$ & $6.5 \pm 0.6 \dagger$ & $4.9 \pm 0.5$ \\
\hline
\end{tabular}

Follicle diam. (mm)

No. of granulosa cells recovered $\times 10^{-6}$

Oestradiol conc. in follicular fluid $(\mathrm{ng} / \mathrm{ml})$

Testosterone conc. in follicular fluid ( $\mathrm{ng} / \mathrm{ml}$ )

Oestradiol:testosterone ratio

Progesterone conc. in follicular fluid ( $\mathrm{ng} / \mathrm{ml})$

Oestradiol secretion by follicies $(\mathrm{ng} / \mathrm{ml} / 2 \mathrm{~h})$

c.p.m. ${ }^{125}$ I-labelled hCG bound/total granulosa in follicle $\times 10^{-3}$

c.p.m. ${ }^{125}$ I-labelled hCG bound/total theca in follicle $\times 10^{-3}$

$4 \cdot 0+0 \cdot 4$

Values followed by superscript $\dagger$ or * indicate that when those groups are combined and compared with the rest of the groups combined they are significantly different $(P<0.05)$.

follicular fluid, oestradiol:testosterone ratio, oestradiol secreted into the medium during incubation, or binding of ${ }^{125}$ I-labelled hCG to thecal and granulosa cells in 'nonovulatory' follicles (Table 5). However, when the mean value for Groups 9 and 11 combined $(59 \mathrm{ng} / \mathrm{ml})$ was compared with that from Groups 8 and 10 combined $(33 \mathrm{ng} / \mathrm{ml})$, the results indicated that the oestradiol concentration in follicular fluid was significantly $(P<0.05)$ higher in those follicles recovered $2 \mathrm{~h}$ after the start of the LH surge. Similarly, the overall mean testosterone concentration in follicular fluid was significantly $(P<0.01)$ higher in follicles collected $2 \mathrm{~h}$ after the start of the LH surge (371 vs $136 \mathrm{ng} / \mathrm{ml}$ ). In addition, follicles from animals that had been pretreated with progesterone (Groups $10 \& 11: 248 \mathrm{ng} / \mathrm{ml})$ had significantly $(P<0.05)$ higher testosterone concentrations in follicular fluid than those not pretreated (Groups $8 \&$ 9: $182 \mathrm{ng} / \mathrm{ml}$ ). 'Non-ovulatory' follicles recovered from saline-treated ewes (Group 12) had a significantly higher oestradiol:testosterone ratio in follicular fluid than did follicles from any of the other groups. The binding of ${ }^{125}$ I-labelled hCG to thecal tissue was also significantly $(P<0.05)$ higher in those follicles from ewes that had been pretreated 
Table 6. Diameter, granulosa cell number, follicular fluid steroid concentrations and ${ }^{125}$ I-labelled hCG binding to thecal and granulosa tissue of 'ovulatory' follicles recovered from GnRH-treated anoestrous ewes in Exp. 2 (all values are mean \pm s.e.m.)

\begin{tabular}{|c|c|c|c|c|}
\hline & $\begin{array}{c}\text { Group } 8 \\
(2-\mathrm{h} \text { injections } \\
\text { GnRH }(250 \mathrm{ng}) \\
\text { for } 24 \mathrm{~h})\end{array}$ & $\begin{array}{c}\text { Group } 9 \\
\text { (2-h injections } \\
\text { GnRH }(250 \mathrm{ng}) \text { for } \\
24 \mathrm{~h}+125 \mu \mathrm{g} \\
\text { GnRH at } 24 \mathrm{~h})\end{array}$ & $\begin{array}{c}\text { Group } 10 \\
\text { (progesterone } \\
\text { priming }+ \\
\text { 2-h injections } \\
\text { GnRH }(250 \mathrm{ng} \text { ) } \\
\text { for } 36 \mathrm{~h} \text { ) }\end{array}$ & $\begin{array}{c}\text { Group 11 } \\
\text { (progesterone } \\
\text { priming }+2-\mathrm{h} \\
\text { injections GnRH } \\
(250 \mathrm{ng}) \text { for } 36 \mathrm{~h} \\
+125 \mu \mathrm{g} \mathrm{GnRH} \\
\text { at } 36 \mathrm{~h})\end{array}$ \\
\hline $\begin{array}{l}\text { Estimated time of collection } \\
\text { relative to LH surge }(\mathrm{h})\end{array}$ & 0 & +2 & 0 & +2 \\
\hline No. of follicles & 12 & 10 & 13 & 10 \\
\hline Follicle diam. (mm) & $6 \cdot 4 \pm 0.3$ & $5 \cdot 4 \pm 0 \cdot 2$ & $5 \cdot 7 \pm 0 \cdot 2$ & $6 \cdot 2 \pm 0 \cdot 2$ \\
\hline $\begin{array}{l}\text { No. of granulosa cells } \\
\text { recovered } \times 10^{-6}\end{array}$ & $3 \cdot 0 \pm 0 \cdot 2$ & $2 \cdot 9 \pm 0.2$ & $3.7 \pm 0.4$ & $3 \cdot 1 \pm 0 \cdot 2$ \\
\hline $\begin{array}{l}\text { Oestradiol conc. in follicular } \\
\text { fluid }(\mathrm{ng} / \mathrm{ml})\end{array}$ & $332 \cdot 5 \pm 97 \cdot 4$ & $288 \cdot 7 \pm 46 \cdot 3$ & $300 \cdot 0 \pm 62 \cdot 8$ & $371 \cdot 5 \pm 59 \cdot 0$ \\
\hline $\begin{array}{l}\text { Testosterone conc. in } \\
\text { follicular fluid ( } \mathrm{ng} / \mathrm{ml})\end{array}$ & $139 \cdot 5 \pm 66 \cdot 2^{a b}$ & $131 \cdot 4 \pm 18 \cdot 3^{\mathbf{a b}}$ & $78 \cdot 0 \pm 16 \cdot 9^{a}$ & $241 \cdot 0 \pm 31 \cdot 4^{\mathrm{b}}$ \\
\hline Oestradiol:testosterone ratio & $3 \cdot 8 \pm 0 \cdot 7$ & $2.5 \pm 0.4 \dagger$ & $5 \cdot 9 \pm 2 \cdot 1$ & $1 \cdot 8 \pm 0.3 \dagger$ \\
\hline $\begin{array}{l}\text { Progesterone conc. in } \\
\text { follicular fluid }(\mathrm{ng} / \mathrm{ml})\end{array}$ & $59 \cdot 2 \pm 9 \cdot 5$ & $68 \cdot 4 \pm 19 \cdot 3$ & $49 \cdot 6 \pm 13 \cdot 1$ & $83.8 \pm 31 \cdot 8$ \\
\hline $\begin{array}{l}\text { Oestradiol secretion by } \\
\text { follicles }(\mathrm{ng} / \mathrm{ml} / 2 \mathrm{~h})\end{array}$ & $5 \cdot 33 \pm 1 \cdot 26^{\mathrm{a}}$ & $3.98 \pm 0.93^{\mathrm{a}}$ & $3.90 \pm 0.48^{\mathrm{a}}$ & $11.93 \pm 2.48^{b}$ \\
\hline $\begin{array}{l}\text { c.p.m. }{ }^{125} \text { I-labelled hCG } \\
\text { bound/total granulosa in } \\
\text { follicle } \times 10^{-3}\end{array}$ & $13 \cdot 2 \pm 2 \cdot 1^{a}$ & $7 \cdot 3 \pm 1.9^{\mathrm{a}}$ & $18 \cdot 1 \pm 4 \cdot 0^{+a}$ & $35 \cdot 3 \pm 8 \cdot 3 \dagger^{b}$ \\
\hline $\begin{array}{l}\text { c.p.m. }{ }^{125} \text { I-labelled hCG } \\
\text { bound } / \text { total theca in } \\
\text { follicle } \times 10^{-3}\end{array}$ & $5 \cdot 2 \pm 2 \cdot 4$ & $6.9 \pm 1.9$ & $10.7 \pm 1.7 \dagger$ & $11.7 \pm 2.8 \dagger$ \\
\hline
\end{tabular}

with progesterone (Groups $10 \& 11: 6.7 \times 10^{3}$ c.p.m. bound) than those that had not (Groups $8 \&$ 9: $4.1 \times 10^{3}$ c.p.m. bound).

There were no significant differences between treatment groups in terms of follicle diameter, granulosa cell content or oestradiol and progesterone concentrations in follicular fluid of 'ovulatory' follicles (Table 6). However, testosterone concentration in follicular fluid was significantly $(P<0.05)$ increased by the LH surge in the progesterone-pretreated animals but not in the non-primed animals. The oestradiol:testosterone ratio was significantly $(P<0.05)$ lower in follicles recovered during the surge (Groups $9 \& 11: 2 \cdot 1$ ), than in those recovered before the surge (Groups 8 $\& 10: 4 \cdot 9)$, although the reduction in oestradiol:testosterone ratio attributable to the $\mathrm{LH}$ surge was greater in the progesterone-primed ewes.

Oestradiol secretion was not significantly changed in response to the LH surge in follicles collected from non-progesterone primed ewes, but was significantly $(P<0.01)$ increased in progesterone-primed ewes (Table 6).

Binding of ${ }^{125}$ I-labelled hCG to granulosa cells showed a significant $(P<0.05)$ increase in response to the LH surge in follicles recovered from progesterone pretreated animals, whereas no 
such increase was found in follicles from non-pretreated ewes. In addition, follicles from progesterone-pretreated ewes bound significantly $(P<0.01)$ more ${ }^{125}$ I-labelled hCG overall (Groups $10 \& 11: 25.6 \times 10^{3}$ c.p.m. bound) than did follicles from non-pretreated ewes (Groups 8 \& 9: $10.5 \times 10^{3}$ c.p.m. bound). A similar significant $(P<0.05)$ difference in the overall binding of ${ }^{125} \mathrm{I}$-labelled hCG by thecal tissue was apparent when comparing progesterone-primed and non-primed ewes (11.1 vs 5.9 c.p.m. $\times 10^{3}$ bound $)$.

\section{Discussion}

Although small-dose multiple injections of GnRH alone induced ovulation in seasonally anoestrous ewes, only $22 \%$ of the animals showed normal luteal function unless they were primed with progesterone. However, the mean timings of these preovulatory LH peaks were around $14 \mathrm{~h}$ later than those previously reported (McLeod et al., 1982a), and this may be due to a difference in breed (Romney Marsh compared to Clun Forest ewes). This between-breed difference in the timing of the preovulatory LH peak meant that follicles were recovered earlier than anticipated in Exp. 1 at about 14 and $26 \mathrm{~h}$ before the LH surge. Nevertheless, it was still possible to identify 'ovulatory' and 'non-ovulatory' follicles.

The classifications used in the present study to distinguish between 'ovulatory' and 'nonovulatory' follicles resulted in predicted ovulation rates in both experiments which were very similar to the mean ovulation rates found in vivo, suggesting that the method used to categorize follicles in this study did give reliable results.

The results summarized in Table 4 show that, at least within the parameters measured, there were no significant differences in the maturational characteristics between 'ovulatory' follicles recovered from progesterone-pretreated and non-pretreated ewes in Exp. 1. It is likely that maturational changes did occur between $18 \mathrm{~h}$ and $28 \mathrm{~h}$ after the start of $\mathrm{GnRH}$ treatment in the follicles of the progesterone-pretreated groups, but that these were too small to be detected. Alternatively, they may have involved parameters not measured in this study.

Significant maturational changes within the sheep follicle have been shown to occur during the ascending limb of the LH peak (Webb \& England, 1982a), with oestradiol secretion into culture medium and number of $\mathrm{LH}$ receptors in granulosa cells both increasing. However, in the study by Webb \& England (1982a) and the present study, LH receptor studies were based on a single point analysis and only indicate changes in binding. To demonstrate changes in receptor numbers unequivocally it would be necessary to estimate $\mathbf{B}_{\max }$ and this is not possible with individual sheep follicles. Also, the measurement of oestradiol secretion from a whole follicle over $2 \mathrm{~h}$ in a fixed volume of medium may not be an optimal system for assessing the true secretion rate, but is valid for comparisons between different treatment groups. Within Exp. 2, therefore, it was decided to recover follicles around the time of the LH surge.

In the follicles classified as 'non-ovulatory' in Exp. 2, the major significant differences recorded between groups were in the oestradiol and testosterone concentrations in the follicular fluid. The increases in both parameters within $2 \mathrm{~h}$ of the onset of the LH surge suggest that, although the follicles were 'non-ovulatory', they still responded to the increase of $\mathrm{LH}$ by secreting more testosterone, which in turn resulted in an increase in oestradiol production. In all groups, however, oestradiol concentrations in follicular fluid were still considerably lower than those of testosterone, as would be expected in 'non-ovulatory' follicles (Carson et al., 1981; Webb \& England, 1982b).

When follicles recovered from progesterone-pretreated ewes were compared with those from non-pretreated groups, it was found that progesterone pretreatment significantly increased ${ }^{125}$ I-labelled hCG binding to thecal tissue and testosterone concentrations in follicular fluid. Whether these differences are due directly to progesterone pretreatment or simply to a longer period of exposure to GnRH remain unclear. Furthermore, no attempt was made in this study to classify 'non-ovulatory' follicles as healthy or atretic, and so it is possible that the differences 
between treatment groups are confounded by different proportions of each category of follicles (McNatty et al., 1984).

When 'ovulatory' follicles are considered, only those from the progesterone-pretreated sheep responded to the $\mathrm{LH}$ surge with an increase in testosterone levels. However, this did not result in increased oestradiol concentrations in follicular fluid as it did in 'non-ovulatory' follicles. In the present study oestradiol secretion rates by follicles from progesterone-pretreated animals were significantly enhanced by the onset of the LH surge, although no such increase was noted in follicles from the non-pretreated group. This suggests that the progesterone-primed follicles, but not the non-primed follicles, were going through the final maturational steps before ovulation. The mechanism for this increased secretion may be the significant increase in LH receptors on the granulosa cells in response to the LH surge which was observed only in ovulatory follicles from progesterone-primed ewes. Also, since there were more LH receptors in the theca from follicles of progesterone-primed ewes this may have resulted in more androgen being available as substrate for aromatization and this is confirmed by the significant increase in testosterone concentration in the follicular fluid from progesterone-primed animals. However, in both experiments there were no significant differences between progesterone-primed and non-primed groups in any of the follicle parameters measured before the onset of the LH surge.

Recent evidence suggests that normal luteal function in anoestrous ewes after progesterone priming followed by multiple injections of GnRH is not due solely to the longer time of exposure of developing follicles to episodic LH before the LH surge, since normal luteal function occurs in progesterone-primed ewes even when the LH surge is induced around the time it occurs naturally in non-pretreated animals (McLeod \& Haresign, 1984).

Moreover, about $20-30 \%$ of ovulations in GnRH-treated anoestrous ewes not primed with progesterone do still develop into functionally normal corpora lutea, and therefore a proportion of the follicles studied from the non-primed group will have been normal. In fact two follicles recovered during the $\mathrm{LH}$ surge in Exp. 2 had oestradiol secretion rates and ${ }^{125}$ I-labelled hCG binding to the granulosa cells of an order of magnitude similar to that recorded for follicles from progesterone-pretreated ewes; it is likely that these follicles would have gone on to form normal corpora lutea. As a consequence, any comparison between potentially 'normal' and 'abnormal' follicles, including those made in this study, will be confounded by the presence of a proportion of 'normal' follicles from the non-progesterone primed animals.

O'Shea, Rodgers \& Wright (1984) reported that corpora lutea induced by GnRH injections in anoestrous ewes contained significantly lower numbers of both large and small luteal cells than did those from normal cyclic animals. In the present study there were no differences in numbers of granulosa cells between progesterone-primed and non-primed ewes, but rather in their steroidogenic capacity and receptor content. Indeed, studies of the normal and inadequate corpora lutea induced by the same treatments used in the present experiments have demonstrated that on Day 4 all corpora lutea were of similar weight, suggesting no difference in luteal cell number at the beginning of the luteal phase, but by Day 5 the abnormal corpora lutea began to decline in weight and had almost completely regressed by Day 6 (J. A. Southee \& M. G. Hunter, unpublished observations).

It can therefore be concluded from the present study that, in order to form normal corpora lutea, follicles must go through stages in maturation in response to the $\mathrm{LH}$ surge by increasing $\mathrm{LH}$ receptor numbers and oestradiol secretion and this occurs in all progesterone-pretreated animals. Follicles that do not respond to the LH surge in this manner (the majority of those from nonprogesterone primed ewes) will result in inadequate corpora lutea. Further study is required to determine the mechanism by which progesterone pretreatment ensures that follicles do go through the final maturational stages before ovulation.

We thank the National Institutes for Health for hCG, LH and FSH and Hoechst Pharmaceuticals for supplies of GnRH. 


\section{References}

Baird, D.T. (1978) Pulsatile secretion of LH and ovarian estradiol during the follicular phase of the sheep estrous cycle. Biol. Reprod. 18, 359-364.

Baird, D.T., Swanston, I.A. \& McNeilly, A.S. (1981) Relationship between LH, FSH and prolactin concentration and the secretion of androgens and estrogens by the preovulatory follicle in the ewe. Biol. Reprod. 24, 1013-1025.

Carson, R.S., Findlay, J.K., Clarke, I.J. \& Burger, H.G. (1981) Estradiol, testosterone and androstenedione in ovine follicular fluid during growth and atresia of ovarian follicles. Biol. Reprod. 24, 105-113.

Foster, J.P. \& Crighton, D.B. (1974) Luteinizing hormone $(\mathrm{LH})$ release after single injections of synthetic LH-releasing hormone ( $\mathrm{LH}-\mathrm{RH}$ ) in the ewe at three different reproductive stages and comparison with natural LH release at oestrus. Theriogenology 2, $87-100$.

Foxcroft, G.R., Elsaesser, F., Stickney, K., Haynes, N.B. \& Back, H.L. (1984) Ovarian oestrogen-dependent maturation of the $\mathrm{LH} / \mathrm{FSH}$ surge mechanism during prepubertal development in the gilt. $J$. Endocr. 101, $371-380$.

Haresign, W. \& Lamming, G.E. (1978) Comparison of LH release and luteal function in cyclic and LHRHtreated anoestrous ewes pretreated with PMSG or oestrogen. J. Reprod. Fert. 52, 349-353.

Haresign, W., Foster, J.P., Haynes, N.B., Crighton, D.B. \& Lamming, G.E. (1975) Progesterone levels following treatment of seasonally anoestrous ewes with synthetic LH-releasing hormone. J. Reprod. Fert. 43, 269-278.

Lowry, O.H., Rosebrough, N.J., Farr, A.L. \& Randall, R.J. (1951) Protein measurement with the Folin phenol reagent. J. biol. Chem. 193, 265-275.

Mcleod, B.J. \& Haresign, W. (1984) Evidence that progesterone may influence subsequent luteal function in the ewe by modulating preovulatory follicle development. $J$. Reprod. Fert. 71, 381-386.

McLeod, B.J., Haresign, W. \& Lamming, G.E. (1982a) Response of seasonally anoestrous ewes to smalldose multiple injections of GnRH with and without progesterone pretreatment. J. Reprod. Fert. 65, $223-230$.

McLeod, B.J., Haresign, W. \& Lamming, G.E. (1982b) The induction of ovulation and luteal function in seasonally anoestrous ewes treated with small-dose multiple injections of GnRH. J. Reprod. Fert. 65, 215-221.

McNatty, K.P., Gibb, K., Dobson C. \& Thurley, D.C. (1981) Evidence that changes in luteinizing hormone secretion regulate the growth of the preovulatory follicle in the ewe. J. Endocr. 90, 375-389.
MeNatty, K.P., Ball, K., Gibb, M., Hudson, N. \& Thurley, D.C. (1982a) Induction of cyclic ovarian activity in seasonally anoestrous ewes with exogenous GnRH. J. Reprod. Fert. 64, 93-96.

NeNatty, K.P., Gibb, M., Dobson, C., Ball, K., Coster, J., Heath, D. \& Thurley, D.C. (1982b) Preovulatory follicular development in sheep treated with PMSG and/or prostaglandin. J. Reprod. Fert. 65, 111-123.

McNatty, K.P., Hudson, N.L., Henderson, K.M., Lin, S., Heath, D.A., Gibb, M., Ball, K., McDiarmid, J.M. \& Thurley, D.C. (1984) Changes in gonadotrophin secretion and ovarian antral follicular activity in seasonally breeding sheep throughout the year. $J$. Reprod. Fert. 70, 309-321.

McNeilly, A.S., Hunter, M.G., Land, R.B. \& Fraser, H.M. (1981) Inadequate corpus luteum function after the induction of ovulation of anoestrous ewes by LH-RH or an LH-RH agonist. $J$. Reprod. Fert. 63, 137-144.

McNeilly, A.S., O'Connell, M. \& Baird, D.T. (1982) Induction of ovulation and normal luteal function by pulsed injections of luteinizing hormone in anestrous ewes. Endocrinology 110, 1292-1299.

Moor, R.M., Hay, M.F., Dott, H.M. \& Cran, D.G. (1978) Macroscopic identification and steroidogenic function of atretic follicles in sheep. J. Endocr. 77, $309-318$.

O'Shea, J.D., Rodgers, R.J. \& Wright, P.J. (1984) Morphometric analysis and function in vivo and in vitro of corpora lutea from ewes treated with LHRH during seasonal anoestrus. J. Reprod. Fert. 72, 75-85.

Purvis, K., Illius, A.W. \& Haynes, N.B. (1974) Plasma testosterone concentrations in the ram. J. Endocr. 61, 241-253.

Thorell, J.K., Johansson, B.A. (1971) Enzymatic iodination of polypeptides with ${ }^{125}$ I to high specific activity. Biochem. Biophys. Acta 251, 363-369.

Webb, R. \& England, B.G. (1982a) Identification of the ovulatory follicle in the ewe: associated changes in follicular size, thecal and granulosa cell luteinizing hormone receptors, antral fluid steroids, and circulating hormones during the preovulatory period. Endocrinology 110, 873-881.

Webb, R. \& England, B.G. (1982b) Relationship between LH receptor concentrations in thecal and granulosa cells and in-vivo and in-vitro steroid secretion by ovine follicles during the preovulatory period. $J$. Reprod. Fert. 66, 169-180.

Received 14 May 1985 